\title{
Landfill leachate assessment by hydrological and geophysical data: case study NamSon, Hanoi, Vietnam
}

\author{
N. V. Giang ${ }^{1,2} \cdot$ K. Kochanek ${ }^{3} \cdot$ N.T. Vu ${ }^{1} \cdot$ N. B. Duan ${ }^{1}$
}

Received: 12 October 2017 / Accepted: 29 March 2018 / Published online: 18 April 2018

(c) The Author(s) 2018

\begin{abstract}
The main objective of this study was to assess the impact of the NamSon landfill on subsurface geological structure and hydrological environment by geophysical techniques and hydrochemical analysis of surface and groundwater. The electrical resistivity tomography (ERT), self-potential (SP) and very low frequency (VLF) methods were used for the investigation of geological structure near the landfill. Three profiles ( $900 \mathrm{~m}$ long in total) of the two-dimensional ERT, VLF density sections and 180 SP data points scattered throughout the study area near the disposal site constituted the basis of the data used in analysis. Additionally, surface water and groundwater samples were collected from six sites in the area for the chemical analysis. Interpretations of geophysical data show a low resistivity zone $(<15 \Omega \mathrm{m})$, which appears to be a fully saturated zone with leachate from landfill. The results of the geophysical investigations are not always fully confirmed by the results of hydrochemical analysis. The quality of water in the vicinity of the landfill dramatically decreased over the year (2015-2016) and actions should be taken to inverse this negative trend.
\end{abstract}

Keywords Resistivity tomography $\cdot$ Self-potential $\cdot$ Hydrogeophysics $\cdot$ Leachate $\cdot$ NamSon waste site

\section{Introduction}

One of the major environmental problems caused by the municipal solid waste landfills is the leachate which is a consequence of precipitation, surface run-off, and infiltration or intrusion of groundwater percolating through a landfill, biochemical processes in wastes cells and the inherent water content of wastes themselves. Leachate is produced always when water or another liquid comes into contact with the

K. Kochanek

nguyenbaduan@gmail.com

N. V. Giang

giangdvlmt@gmail.com

N. T. Vu

vuntigp@gmail.com

1 Institute of Geophysics, Vietnam Academy of Science and Technology, A8, 18 Hoang Quoc Viet, CauGiay, Hanoi, Vietnam

2 Faculty of Earth Sciences, Graduate University of Science and Technology, VAST, A21, 18 Hoang Quoc Viet, CauGiay, Hanoi, Vietnam

3 Institute of Geophysics, Polish Academy of Sciences, Ksiecia Janusza 64, 01-452 Warsaw, Poland wastes. The landfill leachate potentially results in contamination of the groundwater and surface water supplies and threatens human health when migrating from the landfill into neighbouring lands and waters. With the growth of population and development of the industry the problem of landfill leachate becomes more and more severe. Generally, the best method of controlling the pollution of environment by the landfill leachate is to treat leachate to remove the hazardous components before they enter the water systems. This is because, once the leachate enters the water bodies, they become very difficult and expensive to clean.

When analysing landfill leachate a number of complex factors should be taken into account, these are, inter alia, solid waste composition, age of the waste, operation of the landfill, hydrogeological conditions in vicinity of the landfill site, rate of the water movement through the waste, landfill temperature, moisture content, $\mathrm{pH}$, landfill chemical and biological activities and seasonal weather variations [1-4]. The methods of characterisation and treatment of landfill leachate have been developing for last 40 years [5-9]. The most often used methods are based on two main catalogues of conventional and advanced technologies. The conventional technologies include physical, chemical and biological techniques of treatment. The advanced 
technologies are introduced to three integration groups of physico-chemical, multibiological and physico-chemical-biological processes [10-13]. Since it is difficult to obtain satisfactory quality using any of those methods by itself, a combination of physical, chemical and biological methods are employed for efficacious treatment of landfill leachate.

NamSon is the biggest landfill in Hanoi and receives more than 5000 tons of domestic waste per day. The landfill leachate is one of the most serious environmental problems in the vicinity of NamSon. During the last decade the landfill and its impact on environment have been the subject of the intensive studies and environmental projects. Hoang et al. [5] used the sequencing batch reactor technique for leachate treatment; Khanh [8], compared the landfill leachate treatment systems in Vietnam and abroad to choose the most suitable technique that would meet the expectations of Vietnamese standards for NamSon. Van et al. [11] published the results of the experimental investigations on using poly aluminium chlorite (PAC) and $\mathrm{UV} / \mathrm{O}_{3}$ that have been conducted for the determination of optimal $\mathrm{pH}$ value, reaction time and PAC concentration for the removal of chemical oxygen demand (COD) and colour for the NamSon landfill. Khai and Quynh Trang [12] analysed the recovery ability of $\mathrm{N}, \mathrm{P}$ in leachate from the NamSon landfill for pre-treatment of ammonium. Nguyen et al. [14] studied the changes in the hydrogeochemical properties of groundwater during dry and rainy seasons in 2011 by analysing the major ions for Hanoi region. Recently, in 2012, a hydrogeological database was developed for Hanoi region, which was used Bui et al. [15, 16] for characteristics of hydrogeological conditions in 240 boreholes covering the NamSon landfill area. Additionally, Thinh and Strokova [17] published the article presenting the land subsidence caused by groundwater exploitation in Hanoi by analysing complex data on geology, hydrology, soil properties, including SocSon district.

In this paper, to deeper understand the influence of the NamSon landfill activity on its closest vicinity, we propose the procedure of analysis of the leachate and assessment of contamination it creates within the context of variation of geological structure, hydrogeological and hydrological conditions nearby the landfill. The geophysical methods, which we apply, have proven to be an efficient and effective means for characterizing the subsurface geology and hydrology associated with landfills. A combination of various geophysical methods as well as geoelectric and electromagnetic techniques used in hydrology and hydrogeology was applied for the research in the north of the NamSon landfill. These techniques were applied in the lowest altitude terrain around the landfill to monitor the volatility of the soil and water environment that may be caused by the landfill operation. We also show the temporal deterioration of the water environment in the proximity of the landfill.
The geophysical characterization of landfills is now a routine practice. Even so, due to the inherent uniqueness of each site, it is necessary to select carefully the method and appropriately design the survey parameters to derive adequate benefit. In many cases, particularly when multiple objectives are to be met, it is best to use complimentary geophysical methods. A variety of techniques can be applied to define landfill properties, leachate circulation, or regional contamination from offsite seepage [18].

The article is built as follows: in the second chapter the study area is described in detail, next section deals with the geological features of the proximity of the NamSon landfill, the fourth chapter defines methodology of the field and laboratory research and describes the results of measurements and last two sections provide discussion of the results and present final conclusions.

\section{Description of the study area}

The NamSon landfill is located in two communes: NamSon and BacSon, SocSon district, Hanoi City. In 1999 (phase 1) the landfill was designed to occupy total land area of 83.5 ha with ten cells buried garbage and 2000 tons of garbage a day. The volume of wastes received steadily increases and currently exceeds 5000 tons/day. In 2014 the first part of the landfill has been filled up completely and now the NamSon phase 2 is being operating with the total area of 75 ha. Currently, solid wastes delivered to the NamSon landfill are not treated properly. While building, the bottom of the landfill was covered with a layer of geotextile which lays on soil and rocks beneath the broken stamping chapped. However, after a long time of use, then the geotextile layer has decomposed $[8,12]$. Therefore, due to the difference of pressures the water flows from the top of landfill (about $30 \mathrm{~m}$ ) towards the floor and subterranean garbage and with the help of subtropical water seepage breaks through the bottom of the landfill aiming at the lower terrain. The fissured rock environment in the bottom of the landfill, with cracks and holes of size and shape different to define enables the water movement through the garbage to the environment. Burial is the most common treatment option of municipal solid waste in NamSon because this is a simple and low-cost technique. However, there are several hazardous components such as batteries, chemicals, heavy metals, etc., that, if not treated well, can be washed out by the water soaking through the landfilled wastes to the surface water, groundwater, causing serious environmental pollution and impact human life. Since the year 2000 the NamSon landfill leachate has been the subject of the combination of froth flotation and biological treatment, but these processes are still not functioning effectively enough. According to the nearby LaiSon village inhabitants, the odours from the landfill are unbearable. In 
both the dry and rainy season the air the villagers inhale and water they use are highly contaminated due to high concentration of poisonous sediments in surface, groundwater and vapours in the proximity of the landfill. Before the landfill operation, no one from the villagers suffered from oncological diseases but nowadays, 40 people reported to have died in the past 3 years of cancer and about a dozen are diagnosed in terminal stage cancer.

\section{Geological features of the study area}

The topography of the case study terrain is fairly simple. The study area is generally hilly with a very soft transition from 10 to $20 \mathrm{~m}$ (see Fig. 1). The study area is located within the region of moist tropical monsoon heat. Average annual rainfall is $1670 \mathrm{~mm}$ and average air humidity is $84 \%$. Contrary to the surface the geological and hydrogeological structure is quite complex (Fig. 2). The aquifers are of the holocene deposits (qh) and pleistocene deposits (qp) [16, 19]. The water layer deposits of Triassic rift $(t)$, exposed in the north of SocSon district, are characterized by slightly better water quality in the Quaternary sediments $[18,20]$. The silver-coloured soil a

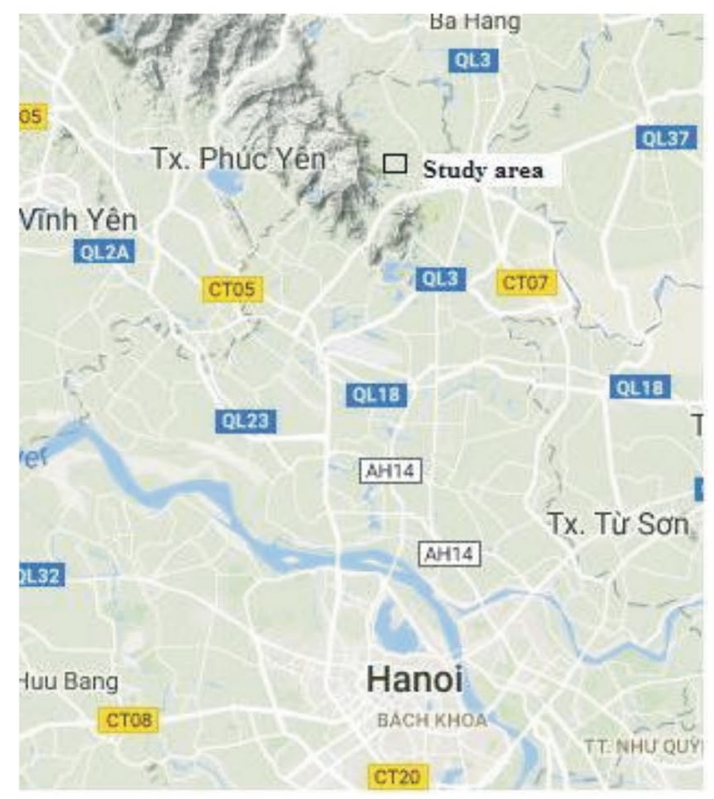

b
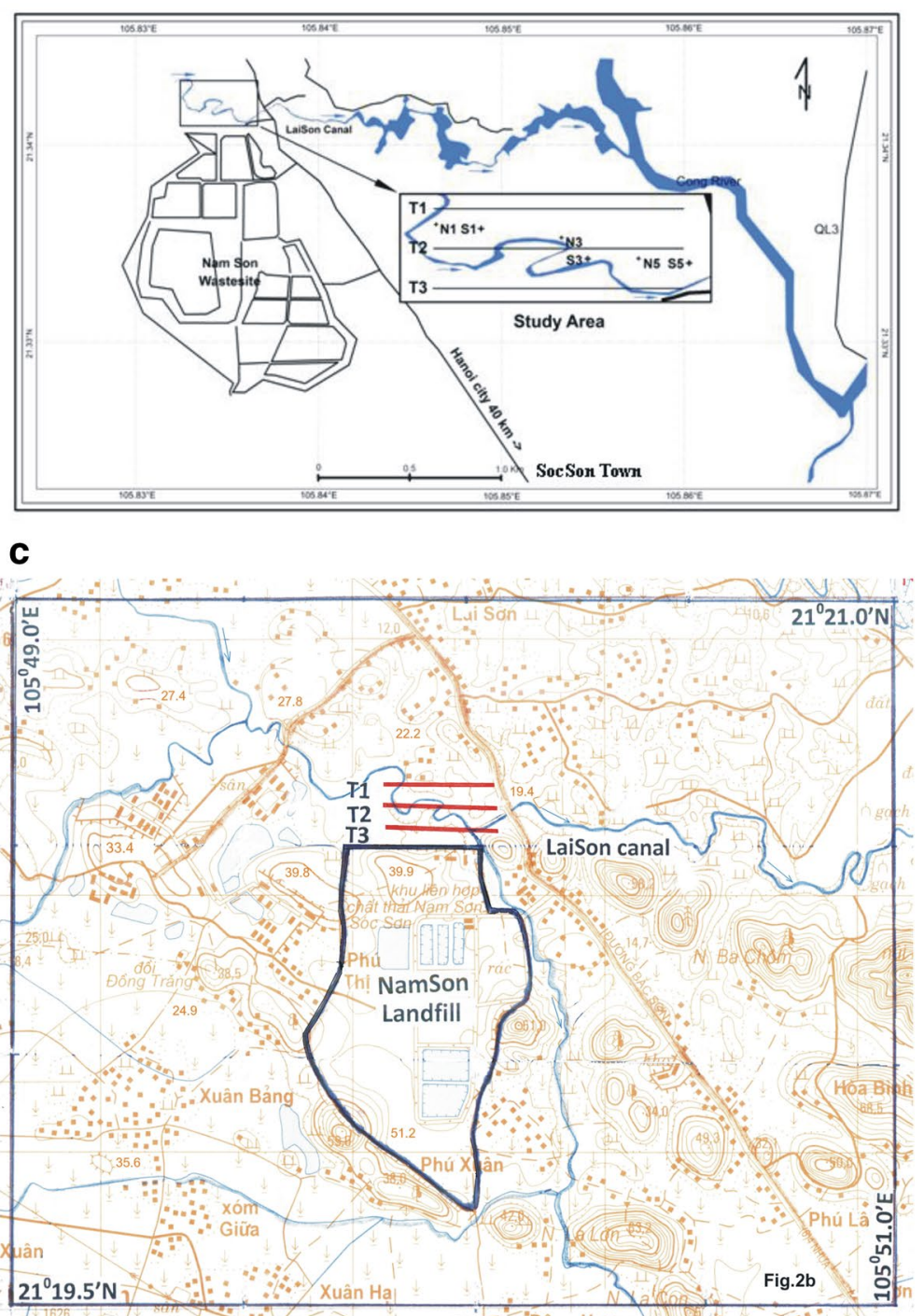

Fig. 1 a Location of the study area north of Hanoi. b Detailed location NamSon waste site and geophysical profiles investigation (T1, $\mathrm{T} 2$, T3) with surface water samples sites $(* \mathrm{~N} 1, * \mathrm{~N} 3, * \mathrm{~N} 5)$ and groundwater samples sites $\left({ }^{+} \mathrm{S} 1,{ }^{+} \mathrm{S} 3,{ }^{+} \mathrm{S} 5\right)$. c The map of elevation for NamSon landfill and the surroundings. Elevation in metres above sea level 


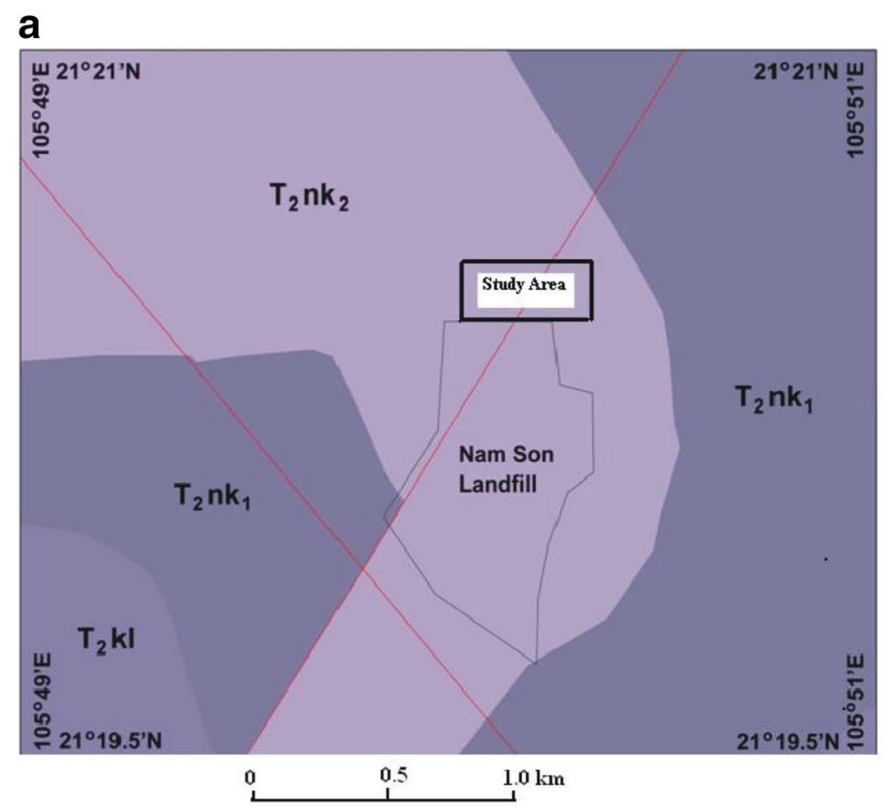

Fig. 2 a Geological map of north SocSon district [22]. b Stratigraphy of boreholes $\mathrm{S} 1, \mathrm{~S} 3$ and $\mathrm{S} 5$ in the study area $[18,19,23] . \mathrm{T}_{2} \mathrm{nk}_{2}$ Upper nk subformation: calcareous sandstone, siltstone, clay shale. $\mathrm{T}_{2}$ b

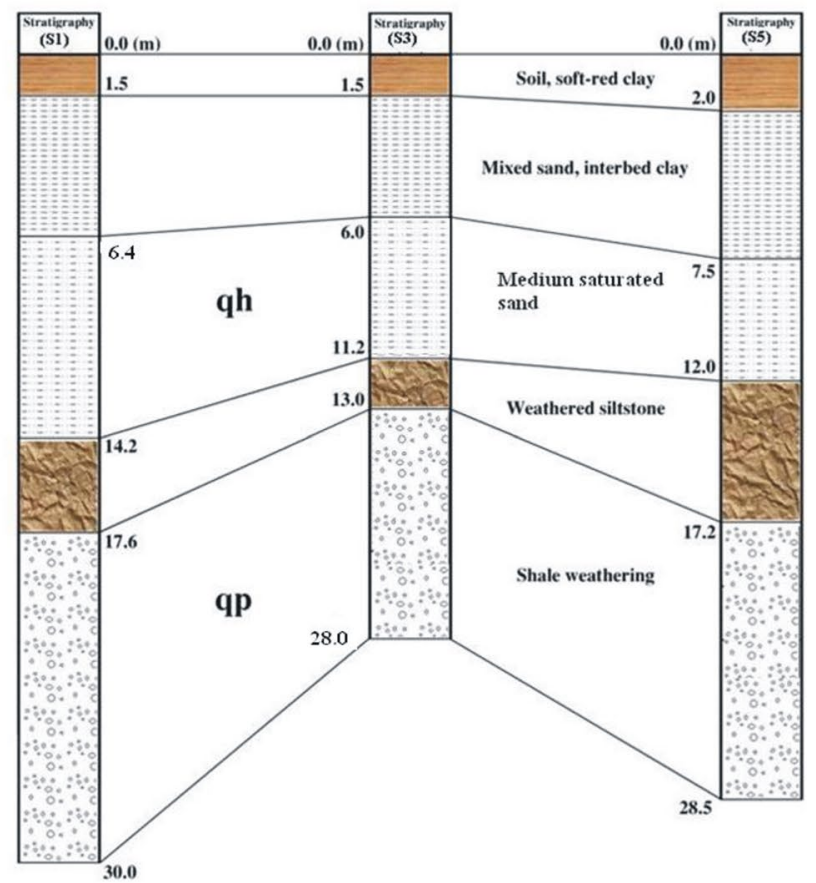

$\mathrm{nk}_{1}$ Lower $\mathrm{nk}$ subformation: sandstone, siltstone, marl. $\mathrm{T}_{2} \mathrm{kl} \mathrm{kl}$ formation: tuffaceous sandstone, silty sandstone, claystone in some parts of the research area is the result of the ancient alluvial ferralitic products [21].

According to the Geology-Mineral map (scale 1:50,000) published in 2015 by the Hanoi Institute of Geology and Environment the structure of SocSon district reveals mainly in the upper Triassic system and the Jura conglomerate [22]. We can also distinguish two stratigraphic formations: the KhonLang (T2a kl) and the NaKhuat (T2 nk). Additionally, there are also two Quaternary stratigraphic units: The ThaiBinh formation (a albQ23, tb) and the Hanoi formation (a, dp, apQ12-3 hn) (Fig. 1).

According to the $28 \div 30 \mathrm{~m}$ deep three boreholes (S1, S3, S5) [18], the stratigraphic column consists of five layers (Fig. 2b):

- From surface to $1.5 \div 2.0 \mathrm{~m}$ : soil, soft-red clay.

- From $1.5 \div 2.0$ to $6 \div 7.5 \mathrm{~m}$ : mixed sand, interbed clay.

- From $6 \div 7.5$ to $11.2 \div 14.2 \mathrm{~m}$ : medium saturated sand.

- From $11.2 \div 14.2$ to $13.0 \div 17.6 \mathrm{~m}$ : weathered siltstone.

- From $13.0 \div 17.6$ to $28 \div 30 \mathrm{~m}$ : shale weathering.

\section{Methodology and results of research}

Our research was divided into two steps: the first one consists on using geophysical methods (supported by the 'classical' borehole measurements) to determine the geological structure, hydrogeological parameters and potential trajectory of leachate under and in the vicinity of the NamSon landfill; the second step requires the in-field and laboratory analysis of the basic physical, chemical and biological properties of surface and groundwater threatened by the landfill leachate. The investigation carried out in March 2015 was repeated in March 2016 and the differences were analysed.

The research area covers $180 \times 300 \mathrm{~m}$ (Fig. 1b) which allows for the optimal use of proposed geophysical methods, namely, self-potential (SP), 2D electrical resistivity tomography (ERT), very low frequency (VLF) combined with the groundwater and surface water sampling with hydrochemical analysis to assess subsurface environmental contamination. 


\section{Geophysical investigations}

Electric and electromagnetic geophysical methods, such as ERT, SP, VLF methods have been widely used for investigating groundwater [6, 24], geological [7, 25-27] and environmental features $[13,28-31]$. Due to the complex morphology of the study area and the difficulty in access to the measurement place, the geoelectrical and electromagnetic methods were applied in this study for shallow geological mapping, particularly for the identification of fractured/saturated or conductive zones.

\section{Self-potential (SP)}

Recently the SP method has been adapted for hydrogeological and water engineering applications, with the use of highly sensitive sensors and the careful application of data correction processes. We adopted a simple SP survey which consists of a base electrode position and a roving electrode to determine potential differences along the profile line survey [32, 33]. Self-potential method makes use of natural currents flowing in the ground that are generated by electro-chemical processes to locate shallow bodies of anomalous conductivity and water circulation. The measurement equipment is very simple and needs only electrodes, a wire and a precise $\mathrm{mV}$ meter. For our case study we used two non-polarizing electrodes constructed by the solution sursaturated in copper sulphate with copper electrode in the middle and we used $\mathrm{mV}$ Terrameter SAS 300C meter for collecting data [34]. Readings are taken with one electrode fixed at a base station and a second one, the mobile 'field' electrode moved along every sampled profile around the survey area. Reading stations are distributed at regular intervals by $5 \mathrm{~m}$ along linear profiles T1, T2 and T3 (Fig. 1b, c). Small potentials (a few mV) are produced by two electrolytic solutions of differing concentrations that are in direct contact and also by the flow of groundwater through the porous materials. The depth of investigation depends on the size of the mineralized body and the depth of the water table for a mineralization potential (generally shallow, less than $30 \mathrm{~m}$ ). The depth of water table for study area is from 4 to $5 \mathrm{~m}$ in dry season $[14,15]$. The SP data interpretation is mainly qualitative (profile, map). The SP anomaly is positive (resurgence) where the hydrostatic pressure decreases (i.e., in the direction of the water flux) and SP anomaly is negative for the infiltration case. Other occurrences produce spontaneous potentials, which may be mapped to determine the information about the subsurface. Spontaneous potentials can be produced by differences in the mineralization of the ground, electro-chemical actions, geothermal activities and bioelectric generation of vegetation. Four different electrical potentials are recognized:

1. Electrokinetic (or streaming) - due to the flow of a fluid with certain electrical properties through a pipe or porous medium of different electrical properties [1, 4].

2. Liquid-junction (or diffusion) — caused by the displacement of ionic solutions of dissimilar concentrations.

3. Mineralization (or electrolytic contact)—produced at the contact of a conductor with another medium.

4. Shale-occurs when similar conductors have a solution of differing concentration [35].

The data collected in the NamSon landfill by the SP method were processed to eliminate noise exemplified by the low background voltages for recognition of different spontaneous-potential sources. After processing, the SP data are in the range of -260 to $+30 \mathrm{mV}$ for the three measured profiles. We aim to assess the relationship of the near-surface geological formation with environmental occurrences, and we use the processed SP data to map by contouring surficial voltages between base/reference electrode( $\mathrm{s}$ ) and the mobile electrodes (Fig. 3a, b). On the map of equipotential based on SP data collected in March 2015 (Fig. 3a) one can distinguish three positive anomalies (marked in brown) and one negative anomaly (in dark blue). The values of the positive SP anomalies are within the range $10-25 \mathrm{mV}$ and negative is equal to $-180 \mathrm{mV}$. After a year (Fig. 3b), however, the SP measurement values changed clearly by six negative SP anomalies with amplitude range from -260 to -180 to $\mathrm{mV}$ and three positive anomalies with amplitude of similar range to this indicated in Fig. 3a. These results may be biased by the groundwater flow which leads to the background voltage variation.

\section{D electrical resistivity tomography (ERT)}

The electrical resistivity tomography (ERT) method belongs to the group of geoelectrical methods commonly used in geophysical engineering. It measures differences in the electrical resistivity of the ground [4, 36-38]. 2D measurements with the use of the ERT method are taken along profiles, in consecutive sequences [39]. The 2D model of the subsurface is more accurate when the resistivity changes in the vertical direction, as well as in the horizontal direction along the survey line [40]. We used SuperSting R1/IP equipment with 56 electrodes [41] for data collection along three profiles T1, T2 and $\mathrm{T} 3$ by Wenner array with 5-m electrode spacing (Fig. 1b, c). The measuring system used automatically broadens distance between electrodes which results in increase in the depth of the measurement. The electrodes are chosen from among the electrodes connected to the cable until there are no more programmed combinations left [42-44]. The 

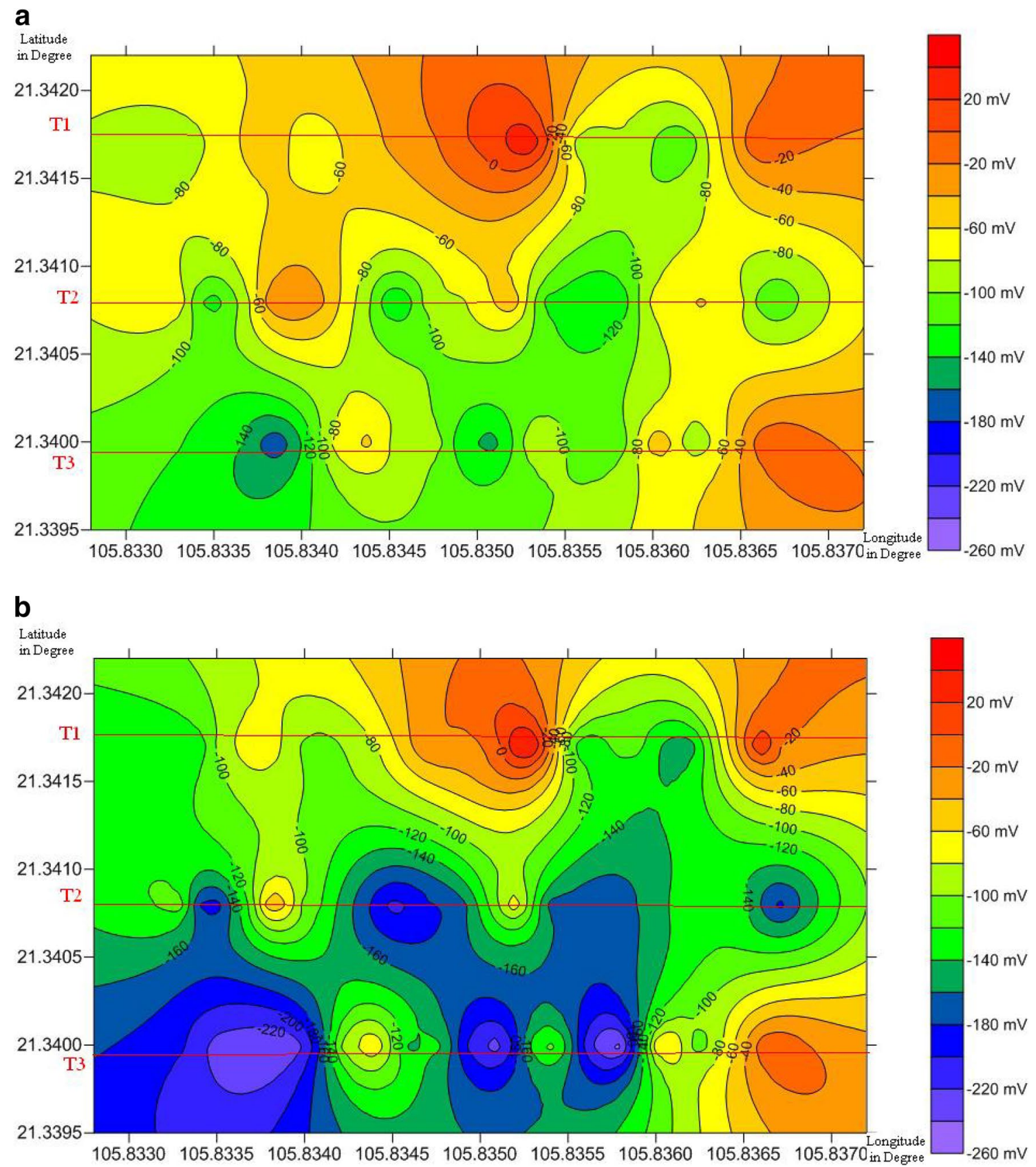

Fig. 3 Map of equipotential based on self-potential (SP) data carried out on a March 2015 and b March 2016

NamSon measurement results are presented in 2D cross-sections showing electrical resistivity vs depth. Interpretation involves confronting given geoelectrical cross-section and its references with subsurface conditions using EarthImager 2D software [41]. The local picture has been ascertained from the electrical resistivity image profile T1(A), T2(A) and T3(A) which were analysed in March 2015 (Fig. 4). The inter-electrode spacing of $5 \mathrm{~m}$ was maintained throughout the $275-\mathrm{m}$ long profile which is W-E oriented. In general, the upper part of the profile shows resistivity values within the range of 10-20 $\Omega \mathrm{m}$ (dark blue colour), 50-70 $\Omega \mathrm{m}$ (green) and 100-130 $\Omega \mathrm{m}$ (yellow) up to $26 \mathrm{~m}$ depth. There is also second level with resistivity values of $150-200 \Omega \mathrm{m}$ (brown) and 250-290 $\Omega \mathrm{m}$ (red) between 20 and $50 \mathrm{~m}$ depth. High resistivity $(>250 \Omega \mathrm{m})$ in the ERT section at the depth of $6 \mathrm{~m}$ in the second portion of the image and a slight increase in the resistivity at the depth of $10 \mathrm{~m}$ indicates the presence of consolidated sandstone with claystone. Resistivity section T1(A), T2(A) and T3(A) represents adequate signal/noise ratio, an important parameter in low resistivity 

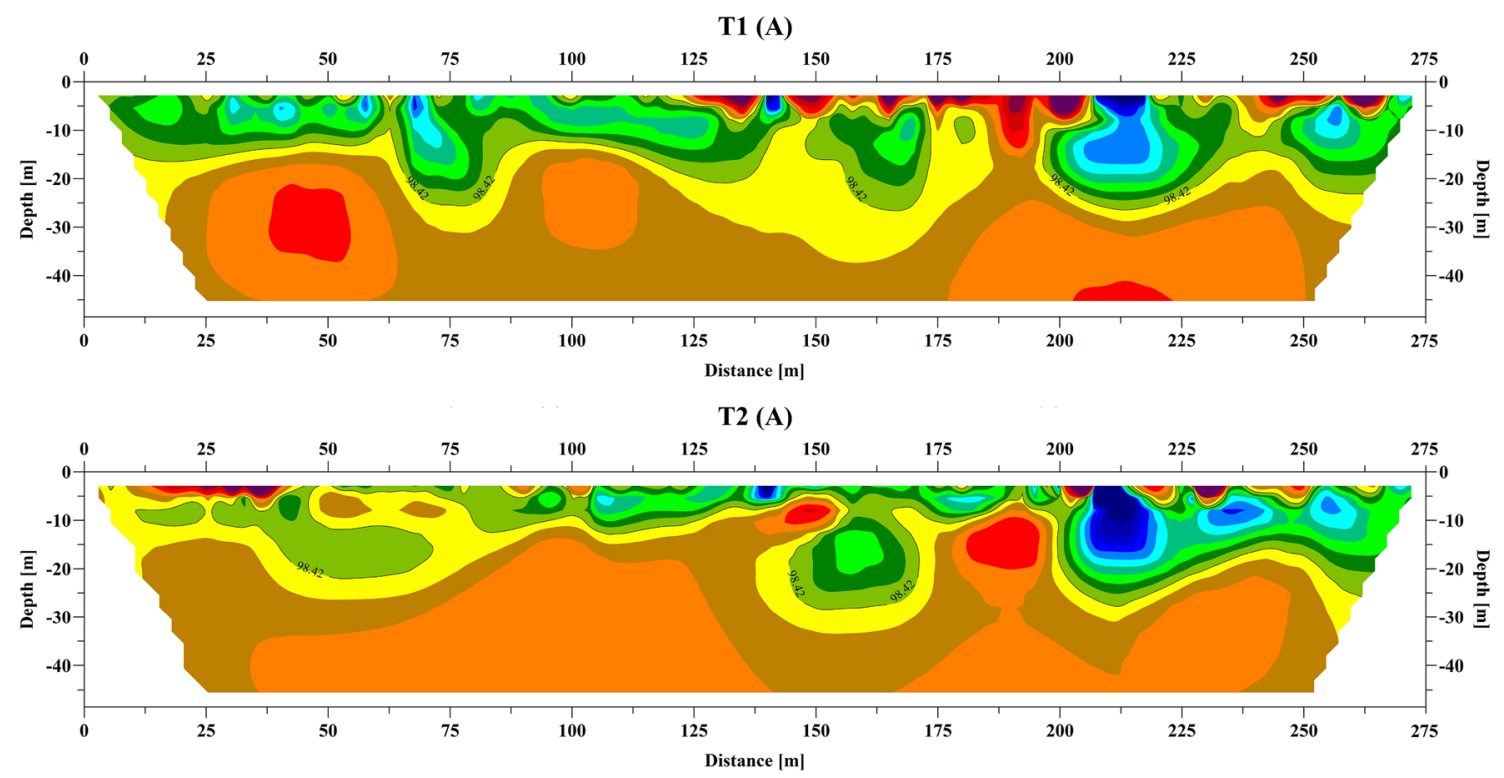

T3 (A)

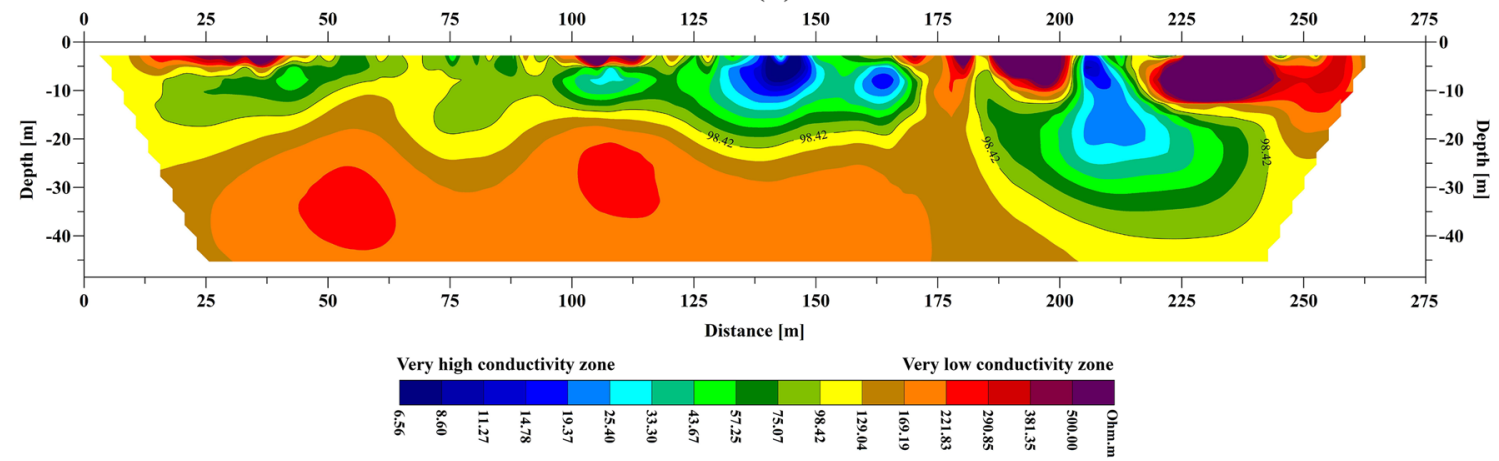

Fig. 4 Inverse model resistivity section of electrical resistivity tomography profile $\mathrm{T} 1(\mathrm{~A})$ by $\mathrm{RMS}=12.78 \%$ and electrode $\mathrm{spacing}=5 \mathrm{~m}$; $\mathrm{T} 2(\mathrm{~A})$ by $\mathrm{RMS}=9.46 \%$ and electrode spacing $=5 \mathrm{~m}$, and $\mathrm{T} 3(\mathrm{~A})$ by $\mathrm{RMS}=12.96 \%$ and electrode spacing $=5 \mathrm{~m}$ which were carried out in March 2015

environments, while it also provides an adequate resolution [35]. The RMS error for iterations of resistivity data varies by $12.78 \%$ for $\mathrm{T} 1$ (A), $9.46 \%$ for T2(A) and $12.96 \%$ for T3(A) in the inverse model resistivity sections. The results suggest delineation of geological formations such as various subsurface lenses like clays and in situ saturated sand-clays up to the depth of several meters. The principal aquifers are formed in the unconsolidated alluvial formations, deposited under various sedimentary environments. The geoelectrical profiles (Fig. 4) show resistivity values that vary laterally with the depth; two levels can be distinguished in accordance with the obtained resistivity values.

After 1 year, also in March (dry season), we repeated the $2 \mathrm{D}$ electrical resistivity measurements by Wenner array with the same multi-electrode resistivity instrument and the measured resistivity profiles were interpreted with the use of the same software. Electrical resistivity values were obtained from three parallel lines (Fig. 5). The RMS error computed for iterations of resistivity data varies by
$11.68 \%$ for $\mathrm{T} 1(\mathrm{~B}), 9.11 \%$ for $\mathrm{T} 2(\mathrm{~B})$ and $9.57 \%$ for $\mathrm{T} 3(\mathrm{~B})$ in the inverse model resistivity sections. The results reveal the lenses at depths of about -16 to $-20 \mathrm{~m}$ in the large are of the case study field with very low resistivity values less than $15 \Omega \mathrm{m}$ (dark blue) in section T1(B), T2(B) and T3(B). According to the $2 \mathrm{D}$ inverted resistivity sections, low values $(<20 \Omega \mathrm{m})$ correspond to areas that may be occupied by contaminated groundwater from leachate. The high resistivity values (>150 $\Omega \mathrm{m}$ ) in profile T1(B), T2(B) and T3(B) are associated with consolidated materials. Additionally, very high resistivity zone $(200-290 \Omega \mathrm{m})$ in profiles A and B are interpreted as consolidated formations, sandstone, siltstone, tuffite and clay shale (Fig. 2).

\section{Very low frequency (VLF)}

Very low frequency (VLF) is a geophysical method commonly used in engineering investigation and environmental studies [4, 35, 45-47]. It is based on the induction of the 


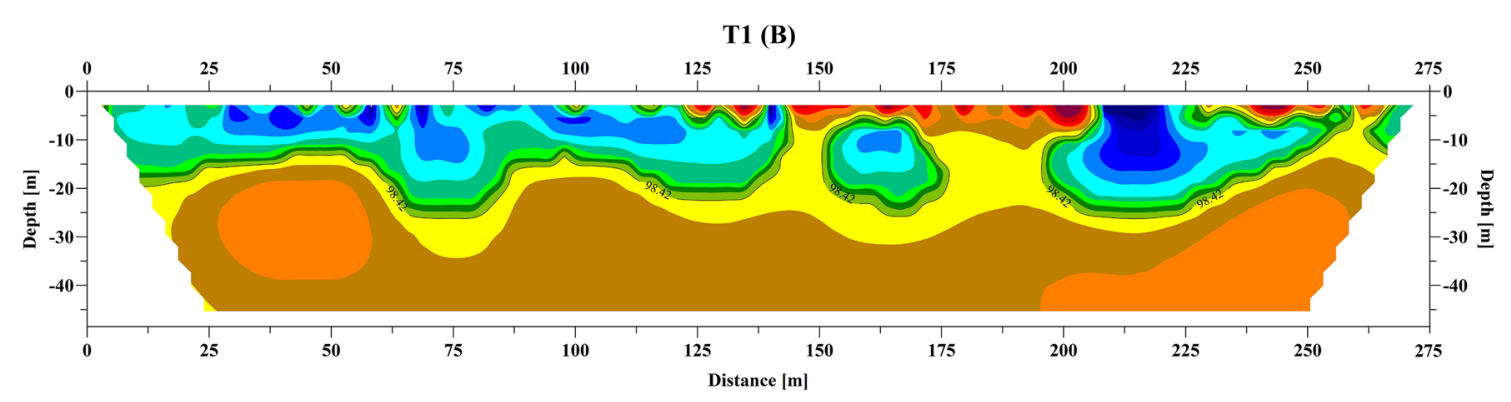

T2 (B)

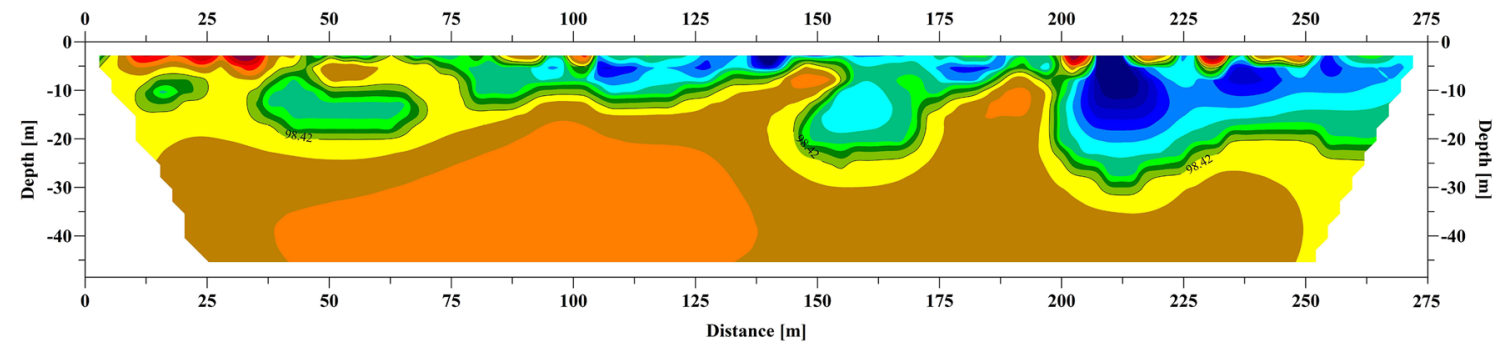

T3 (B)

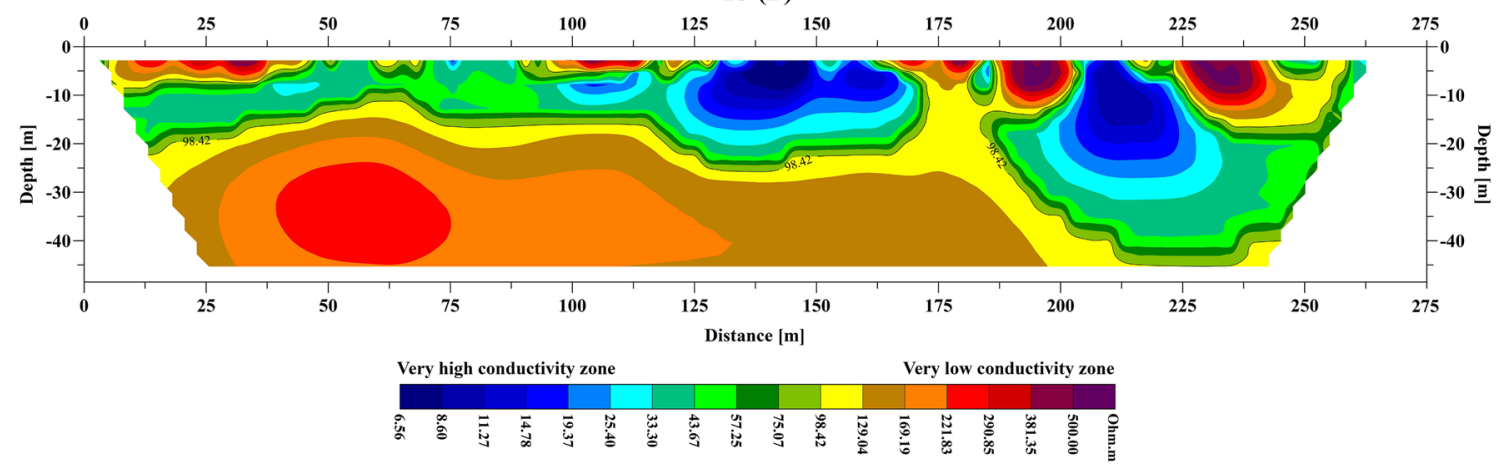

Fig. 5 Inverse model resistivity section of electrical resistivity tomography profiles $\mathrm{T} 1(\mathrm{~B})$ by $\mathrm{RMS}=11.68 \%$ and electrode spacing $=5 \mathrm{~m}$; $\mathrm{T} 2(\mathrm{~B})$ by $\mathrm{RMS}=9.11 \%$ and electrode spacing $=5 \mathrm{~m}$ and $\mathrm{T} 3(\mathrm{~B})$ by $\mathrm{RMS}=9.57 \%$ and electrode spacing $=5$ which were carried out in March 2016

secondary magnetic field $\mathrm{Hs}$ in the subsurface conductor of conductivity $\sigma$ due to the effect of an artificially generated primary field $\mathrm{Hp}$. This means that electric currents in the conducting body (e.g., a fracture) are generated when radio waves (EM field) pass through it, creating another magnetic field (Hs). If the source and receiver are placed near a more conductive zone, stronger eddy currents may be caused to circulate within this zone and an appreciable secondary magnetic field will thereby be created. In close neighborhood of the conductor the secondary or anomalous field may be compared in magnitude to the primary or regular field, in which case it can be detected by the receiver. The secondary field strength, $\mathrm{Hs}$, is usually measured as a proportion of the primary field strength, Hp, at the receiver in percent. The inphase amplitude $\mathrm{Hp}$ is the real component, while the out of phase Hp is the imaginary component or quadrature component. The anomaly is defined as Hs/Hp. The ABEM WADI equipment used for VLF-EM measurements uses military transmitters as the source of primary electromagnetic waves
Hp which is located several km away at the high powered military communication transmission stations. The transmitter's antenna transmits signals continuously at low radio frequency of $15-30 \mathrm{kHz}$.

The VLF measurements in NamSon were accomplished along profiles T1, T2 and T3 (Fig. 1) that ranged in length of $900 \mathrm{~m}$ by a spacing point of $10 \mathrm{~m}$. The selected sites in the field were good criteria for VLF signal which could be acquired from the transmitters of $18-22 \mathrm{kHz}$ frequency. We found it difficult to interpret three VLF curves, so we applied filtering techniques to enhance data and make tiltangle crossovers easier to identify by Karous-Hjelt filter [48]. The real and imaginary parts are presented in the plots by SECTOR software [49] and their interpretation can reveal different types of the VLF data that can be acquired. The real part always shows a positive peak above a conductor, while the imaginary part can show a positive or negative peaks, depending on the conditions of the overburden layer. An interpretation of in-phase (real part) anomaly of the 


\section{a}

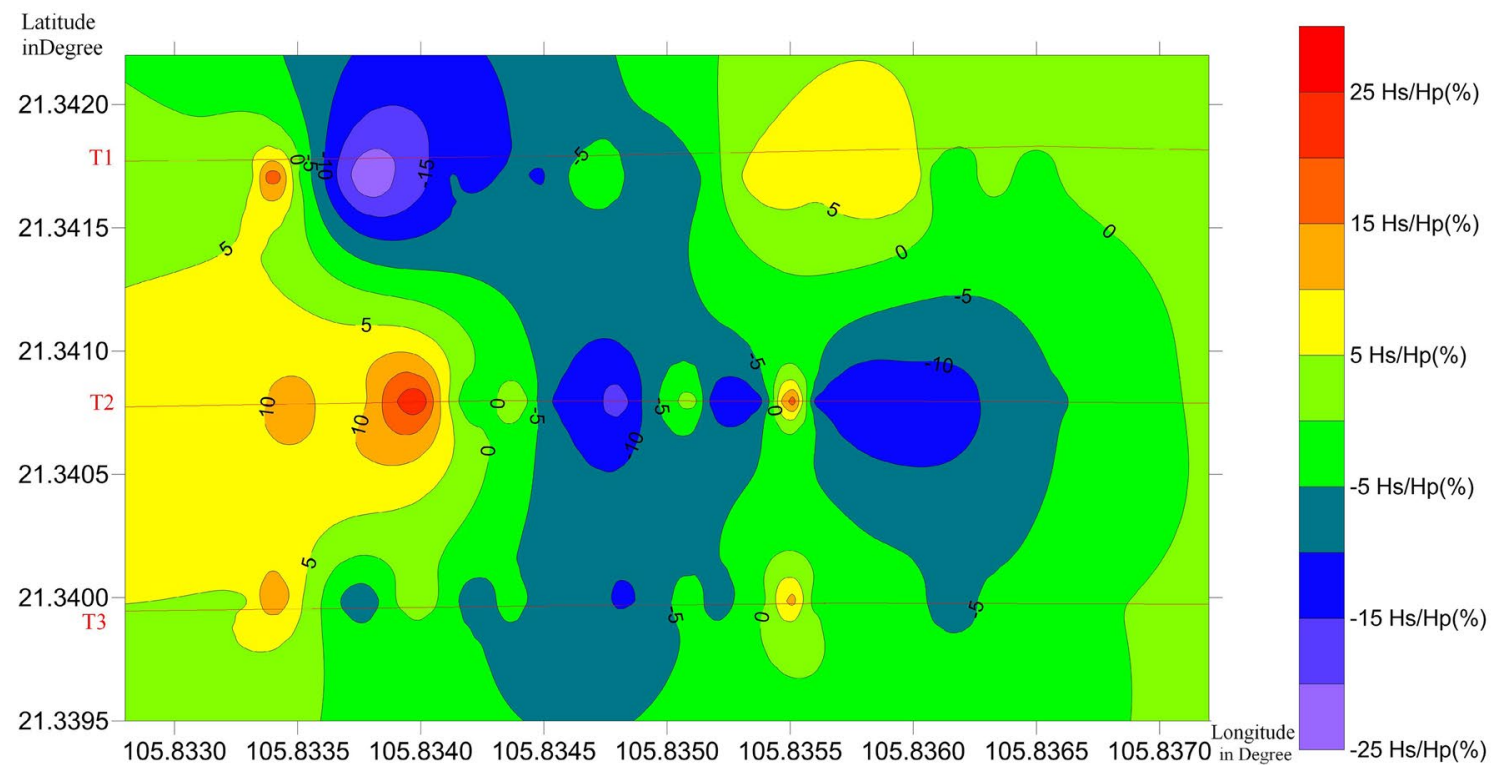

\section{b}

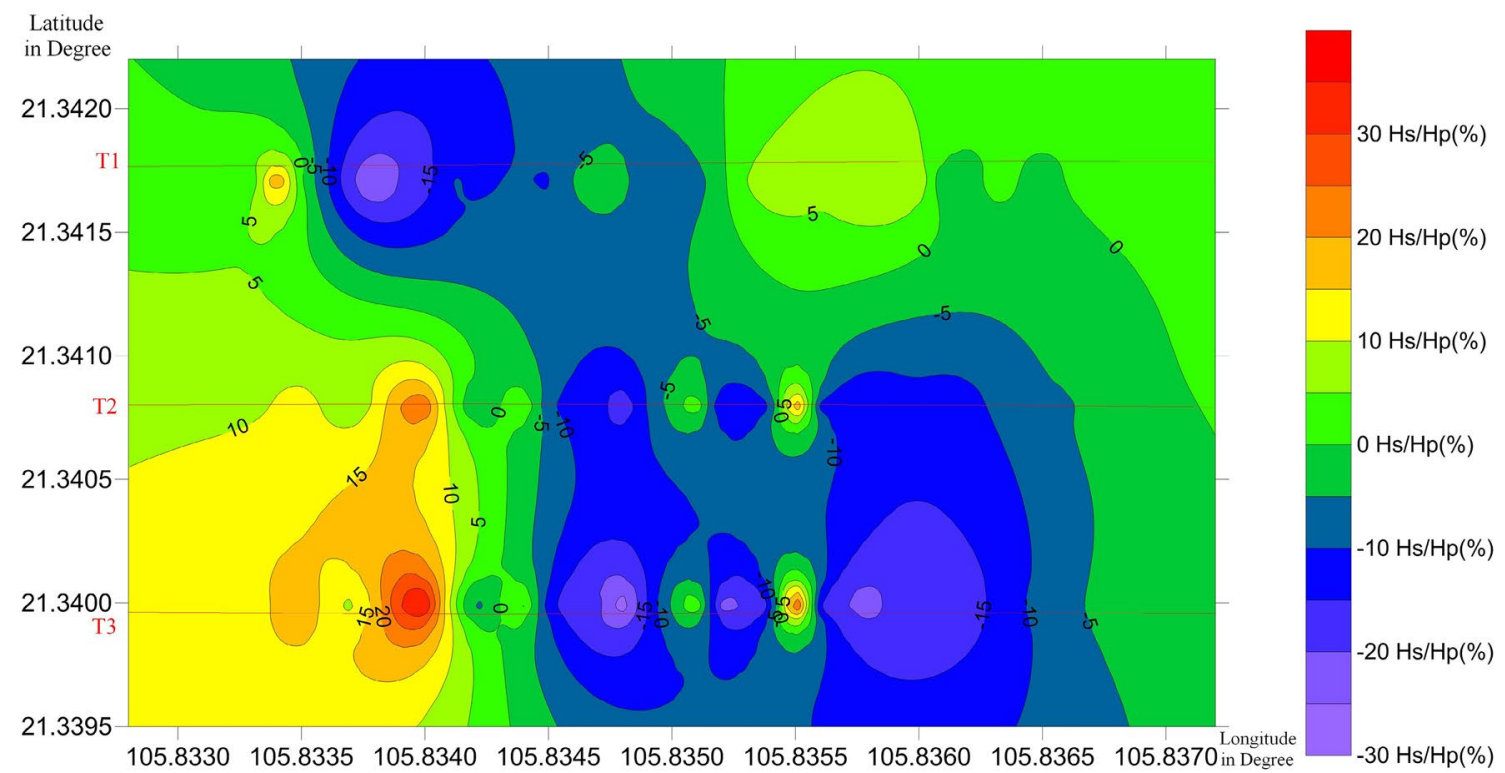

Fig. 6 Distribution of Fraser-filtered in-phase component (in \%) for VLF profiles T1, T2 and T3 carried out in a March 2015 and b March 2016

VLF-EM data was carried out by the analysis of the transform of the in-phase component and the amplitude of its analytic signal. Further, the source and depth to the top of a subsurface conductive body was delineated. The amplitude of the analytical signal of the data was observed to mimic the conventional Fraser-filtered operation and was used to locate the exact location of the anomalous body. The inphase component of the transform yields an approximate depth of $20 \mathrm{~m}$ to the top of the conductor as shown in Fig. 6 . The colour gradation indicates that the anomaly $\mathrm{Hs} / \mathrm{Hp}$ in
$\%$ is (the deeper the colour, the stronger the anomaly): red colour-positive Hs/Hp relationship; blue colour-negative $\mathrm{Hs} / \mathrm{Hp}$ relationship; yellow/green colour-near zero $\mathrm{Hs} / \mathrm{Hp}$ relationship. Negative $\mathrm{Hs} / \mathrm{Hp}$ usually relates to the major resistivity layers, whereas positive anomaly indicates the major electricity conductivity layers (for instance, the presence of clay materials). Successive inflections of $\mathrm{Hs} / \mathrm{Hp}$ indicate the fractured/saturated zones. The current density variation was assumed to indicate the presence of fractures, along the infiltration of leachate. After 1 year, we repeated 
the measurement of the 180 points by the [49], the results are presented in Fig. $6 \mathrm{~b}$ (also $\mathrm{Hs} / \mathrm{Hp}$ in \%) but the picture shows the changes of VLF anomaly by far higher in the position and strength. The anomalous zone of the both times interpreted is located in the middle of the study area with direction from northwest to southeast (NW-SE). This direction indicates from upstream to downstream (direction of the canal LaiSon) and proves that the water infiltration through the landfill strongly influences the quality of surface water to groundwater to the depth of $20 \mathrm{~m}$ by fractured zone in the study area.

\section{Hydrochemical and hydrophysical analysis}

There are many sources of water in the landfill, for example, precipitation, groundwater infiltration, surface run-off, and the disposal of liquids or sludge. The amount of water entering the landfill depends on difficulty to evaluate factors such as the seasonal distribution of the water balance, topography, geological and hydrogeological properties of the site, soil type, land cover, human activity, etc. [50]. Water plays three major roles in land filling: as a medium essential for bacterial activity and for chemical reactions in organic matter, as a medium for movement of contaminants and as a solvent. Obviously, the landfill activities negatively influences the quality of groundwater and surface waters in the neighbourhood [10]. As water percolates through the landfill material, it carries the contaminants from the inorganic and organic waste components degraded by microbial activity to simpler easily soluble compounds. Obviously, percolating through the landfill, water deteriorates in quality, but also changes its colour and odour. The polluting potential of such water may be 10-100 times stronger than the one of the raw sewage. The main components of leachate are the ions of calcium, magnesium, potassium, iron, sodium, ammonium, bicarbonate, sulphate and chloride, trace metals such as manganese, zinc, copper, chromium, nickel, lead and cadmium, a wide variety of organic compounds which are usually measured as total organic carbon (TOC), chemical oxygen demand (COD) or biochemical oxygen demand (BOD). Of course, the individual compounds hazardous at very low concentrations should be considered, too, including pesticides, benzene, phenol, microbiological components $[23,51,52]$.

In this research project, for analysis we sampled surface water in the LaiSon canal at three locations (N1, N3, N5) and groundwater in three boreholes drilled in the area of research (S1, S3, S5) (Fig. 1b). The water level in dry season (March 2016) was $4.2 \mathrm{~m}$ in borehole S1, $5.0 \mathrm{~m}$ in borehole $\mathrm{S} 3$ and $5.8 \mathrm{~m}$ in borehole S5. Then, the sampling depth of water in borehole S1 was $5.0 \mathrm{~m}$, in borehole $\mathrm{S} 3$ was $6.0 \mathrm{~m}$ and in borehole $\mathrm{S} 5$ was $7.0 \mathrm{~m}$.
The water samples were collected and analysed in March 2015 and March 2016 to detect the change in quality. The results of the analysis are presented in Tables 1 and 2, for surface water and groundwater, respectively.

The environmental indicators of water quality can be roughly divided into the physical indicators as temperature, electro-conductivity (EC), total dissolved solids (TDS) and total suspended solids (TSS), the chemical indicators as $\mathrm{pH}$, biological oxygen demand (BOD), chemical oxygen demand (COD), dissolved oxygen (DO), nitrate and heavy metals and biological indicators as bacteria E. coli and coliform. Because direct measurements of water quality are expensive, we used on-site test kits and water samples analysed at laboratories by real-time monitoring.

The Table 1 clearly shows that values of most parameters measured in March 2016 are higher in concentration when compared to 2015. Most of the surface water samples indicated slightly alkaline nature with $\mathrm{pH}$ 7.56-7.95. The values of the $\mathrm{DO}$ for all sites are lower than regular, but the values of the $\mathrm{COD}, \mathrm{BOD}_{5}, \mathrm{NH}_{4}{ }^{+}, \mathrm{NO}_{2}{ }^{-}$, Arsenic, Cadmium, Lead, Copper and Iron are exceeding permissible limits. The values of TDS are recorded in the vicinity of the N3 and N5 (downstream of LaiSon canal) higher than N1 (upstream). Very high values of Coliform and E. coli are also reported in the samples.

As far as the groundwater is concerned (Table 2), the results of analysis show that in 2016 the values of most parameters reveal higher concentration than in 2015. As in case of the surface water, the groundwater is slightly alkaline with $\mathrm{pH}$ varying from 7.07 to 7.80 . The concentration of the TDS in downstream (S3 and S5) is higher than upstream (S1). High values of the COD, Cadmium, Lead, Copper, and Coliform were also sensed in the samples. Furthermore, all the groundwater samples indicated Cyanide concentration exceeding permissible limits. High concentration of the TDS and EC was observed in all wells which mean that the groundwater in the landfill area is of poor quality.

\section{Discussion}

The main objectives of this paper are to present the integrated geophysical methodology of the landfill leachate investigation to assess the physical, chemical and biological temporal degradation of the near-surface geological structure and water bodies in the area of the NamSon landfill. We focused on the effects of the operation of the landfill imposed on the surface water environment, groundwater, sediment by analysis of the water in the formations near the ground, including the rocky land. To accomplish the abovementioned goals, we chose two points in time: March 2015 and March 2016 (dry season) to carry out the survey of water quality and observe the changes in environment around the landfill. 
Table 1 Results of surface water analysis by the Institute of Chemistry and the Institute of Geophysics, VAST

\begin{tabular}{|c|c|c|c|c|c|c|c|c|c|}
\hline \multirow[t]{3}{*}{ No. } & \multirow[t]{3}{*}{ Parameters } & \multirow[t]{3}{*}{ Units } & \multicolumn{6}{|c|}{ Name of samples and content for date } & \multirow{3}{*}{$\begin{array}{l}\text { Standard } \\
\text { QCVN-08- } \\
\text { MT(B1) 2015 }\end{array}$} \\
\hline & & & \multicolumn{2}{|l|}{$\mathrm{N} 1$} & \multicolumn{2}{|l|}{ N3 } & \multicolumn{2}{|l|}{ N5 } & \\
\hline & & & $\begin{array}{l}\text { Mar. 24, } \\
2015\end{array}$ & $\begin{array}{l}\text { Mar. 26, } \\
2016\end{array}$ & $\begin{array}{l}\text { Mar. 24, } \\
2015\end{array}$ & $\begin{array}{l}\text { Mar. 26, } \\
2016\end{array}$ & $\begin{array}{l}\text { Mar. 24, } \\
2015\end{array}$ & $\begin{array}{l}\text { Mar. 26, } \\
2016\end{array}$ & \\
\hline 1 & $\mathrm{pH}$ & $\mathrm{mg} / \mathrm{l}$ & 7.95 & 7.68 & 7.78 & 7.89 & 7.72 & 7.75 & $5.5-9.0$ \\
\hline 2 & DO & $\mathrm{mg} / \mathrm{l}$ & 2.9 & 3.2 & 3.9 & 3.8 & 2.8 & 2.6 & $\geq 4$ \\
\hline 3 & TSS & $\mathrm{mg} / \mathrm{l}$ & 98 & 87 & 32 & 30 & 26 & 37 & 50 \\
\hline 4 & COD & $\mathrm{mg} / \mathrm{l}$ & 233 & 278 & 401 & 444 & 540 & 556 & 30 \\
\hline 5 & $\mathrm{BOD}_{5}$ & $\mathrm{mg} / \mathrm{l}$ & 196 & 202 & 312 & 337 & 341 & 356 & 15 \\
\hline 6 & $\mathrm{NH}_{4}^{+}$ & $\mathrm{mg} / \mathrm{l}$ & 11.5 & 18.7 & 21.0 & 22.7 & 19.4 & 20.3 & 0.9 \\
\hline 7 & $\mathrm{NO}_{2}^{-}$ & $\mathrm{mg} / \mathrm{l}$ & 0.12 & 0.20 & 0.46 & 0.53 & 1.02 & 0.96 & 0.05 \\
\hline 8 & $\mathrm{NO}_{3}^{-}$ & $\mathrm{mg} / \mathrm{l}$ & 3.6 & 5.2 & 8.7 & 9.4 & 15.6 & 16.8 & 10 \\
\hline 9 & $\begin{array}{r}\text { Cyanide } \\
\left(\mathrm{CN}^{-}\right)\end{array}$ & $\mathrm{mg} / \mathrm{l}$ & 0.04 & 0.05 & 0.08 & 0.10 & 0.12 & 0.13 & 0.05 \\
\hline 10 & Arsenic (As) & $\mathrm{mg} / \mathrm{l}$ & 0.08 & 0.08 & 0.15 & 0.15 & 0.14 & 0.17 & 0.05 \\
\hline 11 & $\begin{array}{l}\text { Cadmium } \\
(\mathrm{Cd})\end{array}$ & $\mathrm{mg} / \mathrm{l}$ & 0.03 & 0.06 & 0.09 & 0.08 & 0.12 & 0.13 & 0.01 \\
\hline 12 & Lead $(\mathrm{Pb})$ & $\mathrm{mg} / \mathrm{l}$ & 0.05 & 0.06 & 0.16 & 0.17 & 0.22 & 0.24 & 0.05 \\
\hline 13 & Copper $(\mathrm{Cu})$ & $\mathrm{mg} / \mathrm{l}$ & 0.8 & 0.9 & 1.2 & 1.3 & 1.6 & 1.9 & 0.5 \\
\hline 14 & $\mathrm{PO}_{4}^{3-}$ & $\mathrm{mg} / \mathrm{l}$ & 0.27 & 0.56 & 1.00 & 1.12 & 1.12 & 1.24 & 0.3 \\
\hline 15 & Iron $(\mathrm{Fe})$ & $\mathrm{mg} / \mathrm{l}$ & 1.77 & 1.90 & 1.45 & 1.88 & 1.89 & 2.03 & 1.5 \\
\hline 16 & Total N & $\mathrm{mg} / \mathrm{l}$ & 23.6 & 25.7 & 39.8 & 43.3 & 42.7 & 55.8 & - \\
\hline 17 & Total P & $\mathrm{mg} / \mathrm{l}$ & 2.05 & 2.06 & 3.56 & 3.89 & 4.07 & 5.55 & - \\
\hline 18 & Coliform & MPN/100 ml & 9800 & 10,500 & 10,700 & 11,000 & 11,600 & 12,800 & 7500 \\
\hline 19 & E.-coli & MPN/100 ml & 400 & 500 & 500 & 600 & 500 & 600 & 100 \\
\hline 20 & $\mathrm{EC}$ & $\mathrm{mS} / \mathrm{m}$ & 25.8 & 33.7 & 117.8 & 130.2 & 102.6 & 136.5 & \\
\hline 21 & Temperature & ${ }^{\circ} \mathrm{C}$ & 23.4 & 22.7 & 22.7 & 23.1 & 23.3 & 22.8 & \\
\hline 22 & TDS & ppm & 234 & 267 & 389 & 390 & 443 & 456 & \\
\hline
\end{tabular}

${ }^{a}$ QCVN-08-MT (B1) 2015: Vietnam Technical Regulation on surface water quality by the Ministry of Natural Resources and Environment (MONRE)

The methods chosen to survey the geological structure in the three profiles are based on the conductivity, resistivity, and dielectric constant of the geological environment.

When comparing the map of equipotential based on the self-potential (SP) data carried out on March 2015 (Fig. 3a) and the equivalent map for March 2016 (Fig. 3b) we can see very clearly the negative differences in the quantity, magnitude, as well as, overarching scope related to the location of the SP anomalies. The location of the anomaly peak SP in 2016 changed only slightly in comparison to the year 2015 , but the amplitude of the anomalies changed significantly which points to the negative anomalies which appeared in large numbers nearby the landfill. This was confirmed by the results of the analysis of the quality of the surface- and groundwater.

The model of the electrical resistivity tomographic profiles T1(A), T2(A) and T3(A) in March 2015 (Fig. 4) and the profiles T1(B), T2(B) and T3(B) in March 2016 (Fig. 5) showed apparent difference in the resistivity values reaching as far as ca. $50 \mathrm{~m}$ deep below the ground surface. The investigation revealed that the geological structure is highly inhomogeneous vertically, but fairly homogeneous horizontally. As a result we can observe here good conditions for groundwater run-off, the formation of the lens containing water and different sediments.

The VLF-EM results mapped the shallow linear conductors that are probably the fractured/saturated zones of varying length in the area which is of significant hydrogeologic importance for groundwater bearing. Interpretations are based on the high amplitude signal, which suggests the presence of weathered or fractured zones. The analysis of the VLF data by in-phase component was used to delineate the source and depth to the top of a subsurface conductive body. The amplitude of the analytical signal of the data showed the location of the anomalous body. The anomaly observed in the VLF survey is also associated to the deviation of the measured signal from the regular level, and this deviation is a result of the response of the subsurface geological objects 
Table 2 Result of groundwater analysis by the Institute of Chemistry and the Institute of Geophysics, VAST

\begin{tabular}{|c|c|c|c|c|c|c|c|c|c|}
\hline \multirow[t]{3}{*}{ No. } & \multirow[t]{3}{*}{ Parameters } & \multirow[t]{3}{*}{ Units } & \multicolumn{6}{|c|}{ Name of samples and content for date } & \multirow{3}{*}{$\begin{array}{l}\text { Standard } \\
\text { QCVN-09-MT } \\
2015^{\mathrm{a}}\end{array}$} \\
\hline & & & \multicolumn{2}{|l|}{ S1 } & \multicolumn{2}{|l|}{ S3 } & \multicolumn{2}{|l|}{ S5 } & \\
\hline & & & Mar. 24, 2015 & Mar. 26, 2016 & Mar. 24, 2015 & Mar. 26, 2016 & Mar. 24, 2015 & Mar. 26, 2016 & \\
\hline 1 & $\mathrm{pH}$ & - & 7.67 & 7.25 & 7.72 & 7.49 & 7.23 & 7.18 & $5.5-8.5$ \\
\hline 2 & DO & $\mathrm{mg} / \mathrm{l}$ & 4.6 & 5.1 & 4.9 & 6.0 & 5.9 & 7.0 & - \\
\hline 3 & TSS & $\mathrm{mg} / \mathrm{l}$ & 39 & 44 & 53 & 55 & 67 & 69 & - \\
\hline 4 & COD & $\mathrm{mg} / \mathrm{l}$ & 10 & 19 & 16 & 23 & 24 & 31 & 4 \\
\hline 5 & $\mathrm{BOD}_{5}$ & $\mathrm{mg} / \mathrm{l}$ & 5 & 10 & 11 & 22 & 16 & 40 & - \\
\hline 6 & $\mathrm{NH}_{4}^{+}$ & $\mathrm{mg} / \mathrm{l}$ & 0.22 & 0.31 & 0.26 & 0.42 & 0.30 & 0.44 & 1 \\
\hline 7 & $\mathrm{NO}_{2}^{-}$ & $\mathrm{mg} / \mathrm{l}$ & 0.03 & 0.07 & 0.06 & 0.11 & 0.09 & 0.25 & 1 \\
\hline 8 & $\mathrm{NO}_{3}^{-}$ & $\mathrm{mg} / \mathrm{l}$ & 0.12 & 0.23 & 0.14 & 0.33 & 0.12 & 0.38 & 15 \\
\hline 9 & Cyanide $\left(\mathrm{CN}^{-}\right)$ & $\mathrm{mg} / \mathrm{l}$ & 0.01 & 0.017 & 0.02 & 0.023 & 0.028 & 0.03 & 0.01 \\
\hline 10 & Arsenic (As) & $\mathrm{mg} / \mathrm{l}$ & 0.03 & 0.05 & 0.04 & 0.06 & 0.05 & 0.07 & 0.05 \\
\hline 11 & Cadmium $(\mathrm{Cd})$ & $\mathrm{mg} / \mathrm{l}$ & 0.004 & 0.005 & 0.005 & 0.006 & 0.006 & 0.007 & 0.005 \\
\hline 12 & Lead $(\mathrm{Pb})$ & $\mathrm{mg} / \mathrm{l}$ & 0.02 & 0.03 & 0.03 & 0.03 & 0.03 & 0.04 & 0.01 \\
\hline 13 & Copper $(\mathrm{Cu})$ & $\mathrm{mg} / \mathrm{l}$ & 0.9 & 1.1 & 1.1 & 1.2 & 0.9 & 1.3 & 1 \\
\hline 14 & $\mathrm{PO}_{4}{ }^{3-}$ & $\mathrm{mg} / \mathrm{l}$ & 0.12 & 0.15 & 0.13 & 0.14 & 0.15 & 0.18 & - \\
\hline 15 & Iron $(\mathrm{Fe})$ & $\mathrm{mg} / \mathrm{l}$ & 0.07 & 0.12 & 0.08 & 0.12 & 0.12 & 0.15 & 5 \\
\hline 16 & Total N & $\mathrm{mg} / \mathrm{l}$ & 0.99 & 1.00 & 1.22 & 1.53 & 1.24 & 1.36 & - \\
\hline 17 & Total P & $\mathrm{mg} / \mathrm{l}$ & 0.12 & 0.15 & 0.15 & 0.19 & 0.18 & 0.22 & - \\
\hline 18 & Water level & $\mathrm{m}$ & 4.33 & 5.15 & 4.50 & 5.21 & 4.44 & 5.37 & \\
\hline 19 & $\mathrm{EC}$ & $\mathrm{mS} / \mathrm{m}$ & 45.6 & 58.7 & 56.3 & 77.4 & 69.8 & 87.6 & \\
\hline 20 & Temperature & ${ }^{\circ} \mathrm{C}$ & 25.6 & 25.8 & 24.9 & 25.0 & 25.2 & 25.6 & \\
\hline 21 & TDS & ppm & 115 & 167 & 190 & 232 & 295 & 308 & 500 \\
\hline
\end{tabular}

${ }^{a}$ QCVN-09-MT2015: Vietnam Technical Regulation on groundwater quality by Ministry of Natural Resources and Environment (MONRE)

of interest. The integration of these results shows a main conductive anomalous zone in the northern part of the landfill site that up to 20-30 m deep. Because the measurements of geophysical survey carried out in dry season with the natural surface run-off lets us to draw a conclusion that the conductive anomalous body clearly confirms the presence of leachates. Both the VLF and SP data interpretation provided good response in fractured zones for water moving from upstream to downstream of LaiSon canal which is also reflected by the results of water analysis in 2015 and 2016 . (See Fig. 6a, b the blue colour negative anomaly of VLF data create fractured zone by direction NW-SE and Fig. $3 b$ from SP data by also negative anomaly).

In the sedimentary formation the sand, clay and a finegrained sand formation in the subsurface show minimum resistivity among all the aquifer materials. We observe also the high TDS, EC, Arsenic, Cadmium, Lead, Copper and Iron in S3, S5 and N3, N5 (Tables 1, 2). The higher concentrations may be the consequence of the infiltration of the landfill seepage water flowing to the aquifer and canal. The lower resistivity may be due to the flow of polluted water into the aquifer (see ERT version of three profiles for 2015 and 2016 to confirm of ERT interpretations).
The results of the hydrochemical and hydrophysical analysis showed that the values of $\mathrm{pH}$ for almost all samples ranged within 7.4-7.8, i.e., the water is slightly alkaline [compare 2], but still fits into the allowed safe range. On the other hand, the TDS values for surface and groundwater are very high. Although generally the TDS is not considered as a primary pollutant, it is used as an indication of aesthetic characteristics of domestic water and as an aggregated indicator of the presence of a number of chemical contaminants [10]. Primary sources of the TDS in waters are soil contaminants and polluted water from the landfill [3]. Bear in mind, however, that the concentration of some naturally occurring dissolved solids increases as a result of weathering and dissolution of rocks and soils which influences the results of analyses [53].

The analysis revealed that the concentration of the biological indicators, the $E$. coli and coliform bacteria, is very high especially in surface water. This phenomenon can be explained as follows: The canal always flows according to the slope in the elevation of the terrain, i.e., in this case from NW to SE. It flows through the study area which is not a residential area, but upstream there is a number of farms where the farmers keep livestock such as the pigs and cattle. 
As a result they discharge daily a certain quantity of livestock sewage to the water environment (even though they use water canal for drinking). They also deposit contaminations on the banks of canal that are flushed by the canal water or rain (in rainy season) which influences the high concentrations of Coliform and $E$. coli in samples of surface water. In the dry season, the concentration of feacal Coliform and $E$. coli downstream the canal is caused by the weak flow and accumulation.

Additionally, the eutrophication of the water in the vicinity of the landfill is one of the key environmental problems of the NamSon. Obviously, it results in the sudden growth of plants taking up the nutrients (nitrogen, phosphorus and others) from the water and soil [54]. The result of water analysis showed high values of $\mathrm{P}$ and $\mathrm{N}$ for surface water and groundwater (Tables 1, 2). However, as a result of the increased photosynthetic processes, more oxygen is produced as a byproduct, but in total the eutrophication is always a serious pollution problem. All in all, however, the values of total $\mathrm{P}$ and $\mathrm{N}$ were high in 2015, after 1 year they even increased.

\section{Conclusions}

An integrated, geophysical survey, physical and hydrochemical analysis methods were employed to assess the subsurface geologic formations, aquifer location, dynamics and intrusion of seepage water in the vicinity of the NamSon landfill. The case study area generally close to the ground surface is characterized by the non-homogenous formations which are largely responsible for the transfer of contaminated water into the underlying aquifer. Most of the ionic compositions present in the water effectively indicated the effect of the seepage through the landfill. In water we found particularly high concentration of the TDS, COD, EC, Arsenic, Cadmium, Lead, Copper and Iron. The values of the TDS and some heavy metals concentrations much exceed the standards due to in situ contamination of groundwater in buried soil and soft sediments.

The detected lowering of resistivity is due to the encroachment of very high conductivity of surface water drained by the aquifers and also infiltration of contaminated water from the landfill into the lens and fractured sediments. The equipotential map based on the SP data demonstrates the direction of the water.

The ERT surveys indicated that the subsurface geological structure created favourable conditions for the formation of the lens containing water as well as the tropical disruption by the blocks of sediments. Through such a structure, especially in dry season, the surface water from the LaiSon canal easily infiltrates to the aquifer, which is indicated by the temporal change of the resistivity values. In particular, the field research carried out in March 2016 reveals that the tropical high conductivity structure broadened over time, especially with regard to section T3(B) of the profile measurement located right next to the LaiSon canal. This can be explained by the fact that in the dry season the highly polluted water from the canal is always recharging the aquifer. Poor water quality in the canal is the direct effect of the seepage through the deposits from the landfill.

The results of our research clearly indicate the need of regular monitoring of groundwater and surface water quality in the vicinity of the Nam Son landfill. Also we propose to install the waste water treatment plant that would diminish the pollution of the seepage waters flowing directly to the canal LaiSon. The management of the landfill should also pay more attention to the environmental protection of groundwater resources from the domestic wells in the around landfill area.

Acknowledgements This research is funded by Vietnam National Foundation for Science and Technology Development (NAFOSTED) under Grant Number 105.05-2014.28 and also was carried out within statutory activities No. 3841/E-41/S/2017 of the Ministry of Science and Higher Education of Poland.

Open Access This article is distributed under the terms of the Creative Commons Attribution 4.0 International License (http://creativeco mmons.org/licenses/by/4.0/), which permits unrestricted use, distribution, and reproduction in any medium, provided you give appropriate credit to the original author(s) and the source, provide a link to the Creative Commons license, and indicate if changes were made.

\section{References}

1. Matias MS, Marques da Silva M, Ferreira P, Ramalho E (1994) A geophysical and hydrogeological study of aquifers contamination by a landfill. J Appl Geophys 32:155-162

2. Abudeif AM (2015) Integrated electrical tomography and hydrochemical analysis for environmental assessment of El-Dair waste disposal site, west of Sohag city. Egypt Environ Earth Sci 74(7):5859-5874. https://doi.org/10.1007/s12665-015-4610-5

3. Bhalla G, Kumar A, Bansal A (2011) Assessment of groundwater pollution near municipal solid waste landfill. Asian J Water Environ Pollut 8(1):41-51

4. Sharma PV (1997) Environmental and engineering geophysics. Cambridge University Press, Cambridge

5. Hoang VY, Vasel JL, Le VC (2009) Application of data analysis and experimental planning method to study partial nitrification in treatment of ammonium in landfill leachate in Vietnam. 20th international waste management and landfill symposium, Sardinia, p 8

6. Ganiyu SA, Badmus BS, Oladunjoye MA, Aizebeokhai AP, Ozebo VC, Idowu OA, Olurin OT (2016) Assessment of groundwater contamination around active dumpsite in Ibadan southwestern Nigeria using integrated electrical resistivity and hydrochemical methods. Environ Earth Sci First Online. https://doi.org/10.1007/ s12665-016-5463-2

7. Chambers JC, Kuras O, Meldrum PI, Ogilvy RD, Hollands J (2006) Electrical resistivity tomography applied to geologic, hydrogeologic, and engineering investigations at a former wastedisposal site. Geophysics 71(6):B231-B239 
8. Khanh NH (2007) Research and comparison of landfill leachate treatment system Vietnam and the world to choose suitable one to meet level of Vietnamese standard for landfill site NamSon in Hanoi, report of the project, Institute of Environmental Technology, VAST

9. Paul TI, Debra RR,, Marja E, Roger G, Nitin GBH, Sreeram J, Timothy GT, Ramin Y (2007) Review of state of the art methods for measuring water in landfills. Waste Manag 27:729-745

10. Abu-Zeid N, Bianchini G, Santarato G, Vaccaro C (2004) Geochemical characterization and geophysical mapping of Landfill leachates: the Marozzo canal case study (NE Italy). Environ Geol 45:439-447

11. Van HT, Trinh VT, Dang XH (2012) Treatment of leachate by combining $\mathrm{PAC}$ and $\mathrm{UV} / \mathrm{O}_{3}$ processes. J Vietnam Environ $3(1): 38-42$

12. Khai NM, Quynh Trang HT (2012) Chemical precipitation of ammonia and phosphate from NamSon landfill leachate, Hanoi. Iranica J Energy Environ (Spec Issue Environ Technol) 3:3236. https://doi.org/10.5829/idosi.ijee.2012.03.05.06 (ISSN 2079-2115)

13. Pantelis $\mathrm{S}$, Nikos $\mathrm{P}$, Ilias $\mathrm{P}$, Maria K, Filippos V, Apostolos S, Thrassyvoulos M (2010) Application of integrated methods in mapping waste disposal areas. Environ Geol 53:661-675. https:// doi.org/10.1007/s00254-007-0681-2

14. Nguyen TT, Kawamura A, Tong NT, Nakagawa N, Amaguchi H, Gilbuena R Jr (2014) Hydrogeochemical assessment of groundwater quality during dry and rainy seasons for the two main aquifers in Hanoi, Vietnam. Environ Earth Sci. https://doi.org/10.1007/ s12665-014-3713-8

15. Bui DD, Kawamura A, Tong TN, Amaguchi H, Naoko N (2012) Spatio-temporal analysis of recent groundwater-level trends in the Red River Delta, Vietnam. Hydrogeol J 20:1635-1650

16. Bui DD, Kawamura A, Tong NT, Amaguchi H, Tring TM (2012) Aquifer system for potential groundwater resources in Hanoi. Vietnam Hydrol Process 26:932-946. https://doi.org/10.1002/ hyp. 8305

17. Thinh HP, Strokova LA (2015) Prediction maps of land subsidence caused by groundwater exploitation in Hanoi, Vietnam. Resour Eff Technol 1:80-89. https://doi.org/10.1016/j.reffit.2015.09.001

18. Giang NV, Duan NB, Thanh LN, Hida N (2013) Geophysical techniques to aquifer locating and monitoring for industrial zones in North Hanoi. Vietnam Acta Geophys 61(6):1573-1597. https ://doi.org/10.2478/s11600-013-0147-8

19. Hida N, Giang NV (2012) Decline in groundwater levels in Thang Long industrial park within the area of Northwest Hanoi. Vietnam J Jpn Assoc Hydrol Sci 42(4):167-172 (Japanese)

20. Thuy NT, Kawamura A, Thanh TN, Nakagawa N, Amaguchi H, Gilbuena R Jr (2015) Hydrogeochemical assessment of groundwater quality during dry and rainy seasons for the two main aquifers in Hanoi, Vietnam. Environ Earth Sci 73(8):4287-4303. https:// doi.org/10.1007/s12665-014-3713-8

21. Tanabe S, Hori K, Saito Y, Haruyama S, Vu PV, Kitamura A (2003) Song Hong (Red River) delta evolution related to millennium-scale Holocene sea-level changes. Quat Sci Rev 22:2345-2361

22. Sam DX (ed) (2010) The natural conditions of the natural resources and the environment in the development of space-oriented Hanoi capital, Hanoi Published House, p 590 Ha Noi, Viet Nam (in Vietnamese)

23. Giang NV, Thanh LN, Hiep VQ, Hida N (2014) Hydrological and hydrogeological characterization of groundwater and river water in the North Hanoi industrial area, Vietnam. Environ Earth Sci 71(11):4915-4924. https://doi.org/10.1007/s12665-014.3086-z

24. Gupta G, Patil J, Maiti S, Erram VC, Pawar N, Mahajan S, Suryawanshi R (2015) Electrical resistivity imaging for aquifer mapping over Chikotra basin, Kolhapur district, Maharashtra. Environ Earth Sci 73:8125-8143

25. Bernstone C, Dahlin T, Ohlsson T, Hogland W (2000) DC-resistivity mapping of internal landfill structures: two pre-excavation surveys. Environ Geol 39(3-4):360-368

26. Cardarelli E, Fischanger F (2006) 2D data modelling by electrical resistivity tomography for complex subsurface geology. Geophys Prospect 54:121-133

27. Kumar D (2012) Efficacy of ERT technique in mapping shallow subsurface anomaly. J Geol Soc India 80:304-307

28. Guerin R, Begassat Ph, Benderitter Y, David J, Tabbagh A, Thiry M (2004) Geophysical study of the industrial waste land in Mortagne-du-Nord (France) using electrical resistivity. Near Surf Geophys 3:137-143

29. Porsani JL, Filhob WM, Vagner RE, Shimelesa F, Douradob JC, Moura HP (2004) The use of GPR and VES in delineating a contamination plume in a landfill site: a case study in SE Brazil. J Appl Geophys 55:199-209

30. Maillet GM, Rizzo E, Revil A, Vella C (2005) High resolution electrical resistivity tomography (ERT) in a transition zone environment: application for detailed internal architecture and infilling processes study of a Rhône River paleo-channel. Mar Geophys Res 6:317-328. https://doi.org/10.1007/s1100 1-005-3726-5

31. Martinho E, Almeida F (2006) 3D behaviour of contamination in landfill sites using 2D resistivity/IP imaging: case studies in Portugal. Environ Geol 49:1071-1078

32. Corwin RF (1990) The self-potential method for environmental and engineering applications. Geotech Environ Geophys $1: 127-145$

33. Frederico R, Phygeo W, Márcio M, Guilherme M, Paulo KNA (2013) The self-potential (SP) method applied for investigating the contamination in the vicinity of the Estrutural city landfill, in Brasilia-DF. In: 13th international congress of the Brazilian Geophysical Society. Rio de Janeiro, Brazil, pp 1-4

34. SAS 300C Terrametter instrument manual introduction (1995). ABEM, Sweden

35. Telford WM, Geldart LP, Sheriff RE (1990) Applied geophysics, 2nd edn. Cambridge University Press, Cambridge, UK, p 792

36. Keller GV, Frischknecht FC (1966) Electrical methods in geophysical prospecting. Pergamon Press Inc., Oxford

37. Loke MH, Barker RD (1996) Rapid least squares inversion of apparent resistivity pseudosections by a quasi-Newton method. Geophys Prospect 44:131-152

38. Smith RC, Sjogren DB (2006) An evaluation of electrical resistivity imaging (ERI) in Quaternary sediments, southern Alberta, Canada. Geosphere 2(6):287-298

39. Sudha K, Israil M, Mittal S, Rai J (2009) Soil characterization using electrical resistivity tomography and geotechnical investigations. J Appl Geophys 67:74-79

40. Loke MH (2000) RES2DINV version 3.44 for windows $95 / 98$ and NT: rapid 2D resistivity and IP inversion using the least squares method. Advanced Geosciences Inc., Austin

41. AGI, (2003), The SuperSting with Swift automatic resistivity and IP system instruction manual. Advanced Geosciences, Inc., Austin

42. Griffiths DH, Barker RD (1993) Two-dimensional resistivity imaging and modeling in areas of complex geology. J Appl Geophys 29:211-226

43. Frid V, Liskevich G, Doudkinski D, Korostishevsky N, (2008), Evaluation of landfill disposal boundary by means of electrical resistivity imaging. Environ Geol 53:1503-1508. https://doi. org/10.1007/s00254-007-0761-3

44. Andrea TU, Vagner RE, Giulliana M, Lazaro VZ, Heraldo LG (2012) Case study: a 3D resistivity and Induced polarization imaging from downstream in waste disposal site in Brazil. Environ Earth Sci 66:763-772 
45. Benson AK, Payne KL, Stubben MA (1997) Mapping groundwater contamination using dc resistivity and VLF geophysical methods-a case study. Geophysics 62(1):80-86 (USA: Society of Exploration Geophysicists)

46. Gharibi M, Pedersen LB (1999) Transformation of VLF data into apparent resistivities and phases. Geophysics 64(5):1393-1402

47. Karlik G, Kaya MA (2001) Investigation of groundwater contamination using electric and electromagnetic methods at an open waste-disposal site. A case study from Isparta, Turkey. Environ Geol 40(6):725-731

48. Karous M, Hjelt SE (1983) Linear filtering of VLF dip-angle measurements. Geophys Prospect 31:782-794

49. VLF WADI-instrument manual introduction (1995). ABEM, Sweden

50. Ahmed A, Sulaiman W (2001) Evaluation of groundwater and soil pollution in a landfill area using electrical resistivity imaging survey. Environ Manag 28(5):655-663
51. Meju MA (2000) Geoelectrical investigation of old/abandoned landfill sites in urban areas: model development with a genetic diagnosis approach. J Appl Geophys 44:115-150

52. Meju MA (2006) Geoelectrical characterization of covered landfill sites: a process-oriented model and investigative approach. In: Vereecken H, Binley A, Cassiani G, Revil A, Titov K (eds) Applied hydrogeophysics. Springer, Dordrecht, pp 319-339

53. Rapti-Caputo D, Vaccaro C (2006) Geochemical evidences of landfill leachate in groundwater. Eng Geol 85:111-121

54. WHO, (2007), Water for pharmaceutical use in quality assurance of pharmaceuticals A compendium of Guidelines and Related materials, 2nd edn. World Health Organization, Geneva, pp 170-187 